\title{
A model of immunohistochemical differences between invasive breast cancers and DCIS lesions tested on a consecutive case series of 1248 patients
}

Sven Kurbel ${ }^{1^{*}}$, Ksenija Marjanović ${ }^{2}$ and Branko Dmitrović ${ }^{2}$

\footnotetext{
* Correspondence: sven@jware.hr 'Department of Physiology, Osijek Medical Faculty, Osijek, Croatia Full list of author information is available at the end of the article
}

\begin{abstract}
Background: A previous theoretic model (Tumour Biol 2013;34:1-7.) that breast tumor types differ in the relative rate of tissue invasion was elaborated and developed on a consecutive case series.

Method: Histologic data of 68 ductal breast cancer in situ (DCIS) and 1180 invasive ductal cancer (IDC) patients were collected and analyzed.

Results: $\mathrm{ER}^{+} \mathrm{PgR} \mathrm{R}^{-}$phenotype was more common in Luminal B2 than among the pooled Luminal A\&B1 $(p=0.0002)$, and more frequent in Luminal B1 than in Luminal $A$ $(p=0.0167)$. The same phenotype was associated with the age older than 54 years in Luminal B1 and in B2 patients. HER2 type cancers were more frequent in older patients $(p=0.0038)$.

Tumor progression from DCIS to IDC was found 39\% faster than the average in Luminal B1 tumors, supporting the clinical importance of this tumor type. A rare combination of low Ki-67 in HER2 type cancers (only 14\% of HER2 type cancers) showed very slow transition to IDC (occurring at only $53.55 \%$ of average progression rate), while triple-negative cancers progressed faster than the average, despite Ki-67 value (104.63\% for low and $114.27 \%$ for high Ki-67 tumors).

In three tumor types with positive steroid receptors the $\mathrm{ER}^{+} \mathrm{PgR}^{-}$phenotype showed slower IDC transition than the $\mathrm{ER}^{+} \mathrm{Pg} \mathrm{R}^{+}$phenotype of the same tumor type (difference in progression rate was 38\% for Luminal A, 46\% for Luminal B1 and 67\% for Luminal B2 with Ki67 > 14\%).

Triple-negative tumors in younger patients exceeded the expected average progression rate by $24 \%$, while in HER2 type tumors, the rate of tissue invasion was in younger patients 20\% lower than the expected value.

Conclusions: The relative rate of tissue invasion differed substantialy among our patients. Differences depended on tumor types, steroid expression phenotypes and age. The dysfunctional ERs in the $\mathrm{ER}^{+} \mathrm{Pg} \mathrm{R}^{-}$phenotype showed slower rates of tissue invasion, suggesting that ligand binding to functional breast tumor ERs, beside promoting the PgR expression, possibly also promotes tumor transition to the invasive phase.

In triple-negative tumors, an age dependent premenopausal mechanism possibly acted as an accelerator of tissue invasion, while faster tissue invasion by HER2-overexpressed tumors in older patients possibly depended on an unidentified mechanism that takes more time to be acquired, so it was less present in premenopausal patients.
\end{abstract}

\section{Biomed Central}

(c) 2014 Kurbel et al.; licensee BioMed Central Ltd. This is an Open Access article distributed under the terms of the Creative Commons Attribution License (http://creativecommons.org/licenses/by/2.0), which permits unrestricted use, distribution, and reproduction in any medium, provided the original work is properly credited. The Creative Commons Public Domain Dedication waiver (http://creativecommons.org/publicdomain/zero/1.0/) applies to the data made available in this article, unless otherwise stated. 


\section{Introduction}

Ductal breast cancer in situ (DCIS) seems to precede invasive ductal cancer (IDC). This idea is based on a high degree of similarity between molecular alterations in DCIS and invasive cancer in the same patient [1,2], although triple-negative invasive cancers may seem almost to lack their triple-negative DCIS precursor [3-6].

If all breast cancer types evolve from DCIS lesions, more aggressive breast cancer types can be recognized by comparing breast tumor type distributions between DCIS lesions and invasive breast cancers [1]. The basic idea is that at the time of breast tumor diagnosis more aggressive tumor types will have fewer DCIS lesions in comparison to less aggressive types with more tumors still in the DCIS phase.

This model, based on reported data of breast cancer characteristics pooled from several studies, was proposed in a recent theoretic article [1]. Differences in the incidences of the main breast cancer types (Luminal A, Luminal B, HER2overexpressed and the triple-negative tumors) between DCIS and invasive ductal cancers (IDC) were used to calculate the relative rate of progression from the in situ stage to invasive form. This calculated value is probably not directly related to the course of disease. Instead, it was designed as a parameter that defines chances of a certain tumor to become invasive at the time of diagnoses. In other words, we were trying to indirectly measure the speed of the critical phase in breast cancer development.

After becoming invasive, the future growth depends on many factors. For instance, HER2-overexpressed tumors were found in the theoretic model to be very slow in tissue invasion [1], although further development of HER2-overexpressed invasive breast cancers, is well known as aggressive and rapid. Triple-negative tumors showed in the pooled model the most rapid rate of tissue progression and this finding was interpreted as a sign of an unrecognized tumor progression mechanism, independent of steroid receptors or HER2 expression.

Further to investigate the idea that immunohistochemical characteristics of IDC and of DCIS tumors from a defined single population can help us to describe biology of breast tumor types, a sufficiently large sample was required of DCIS and IDC patients with defined tumor types, ER, PgR, HER2 status and other histological features. The need for all these data comes from reported breast cancer studies [7-12] that suggested that PgR expression in cells with ER depends on estrogen exposure during previous days. In other words, ligand binding to functional ERs is a physiologic prerequisite for PgR expression in breast tumor cells. This clearly suggests that the three possible positive steroid receptor breast cancer phenotypes $\left(\mathrm{ER}^{+} \mathrm{Pg} \mathrm{R}^{+}, \mathrm{ER}^{+} \mathrm{Pg} \mathrm{R}^{-}\right.$and the rare $\left.\mathrm{ER}^{-} \mathrm{Pg} \mathrm{R}^{+}\right)$may be biologically different, particularly in this early phase of tumor growth, during tissue invasion.

Without a suitably detailed published data set from a single population, the only solution was to use a single institution experience in diagnosing 68 DCIS and 1180 IDC patients that has already been attained as a part of an ongoing research project (219-2192382-2426), financed by the Croatian Ministry of Science.

The aim of this study was to apply numeric methods described in the previous theoretic paper [1] on real patient data and thus get more reliable answers on the possible mechanisms underlying the occurrence of breast cancer types. 


\section{Patients, materials and methods Patients}

Data used for the model testing were taken from the above mentioned ongoing research project (219-2192382-2426), approved by the Ethical Committee of Osijek Medical Faculty as compliant with the Helsinki Declaration, before grant submission to Croatian Ministry of Science and Education.

In this study 1248 consecutive patients with intraductal and/or ductal invasive breast cancers (regardless of stage) were included. All patients were diagnosed and treated in Osijek Clinical Hospital during the time period from January 2004 to December 2012. All specimens were excisional biopsy specimens, or mastectomy specimens. 68 cases were DCIS alone. Tumor grade was determined using the Bloom and Richardson grading scheme [13].

\section{Immunohistochemistry}

Each immunostained slide was evaluated for the presence of ER and PgR expression, HER2 protein overexpression, and Ki-67 proliferation activity. Immunohistochemical staining was done by standard avidin-biotin method (DAKO LSAB 2 System, HRP) using $4 \mu \mathrm{m}$ sections from representative paraffin blocks. Nuclear staining with anti-ER, PgR, Ki-67 antibodies was done and the percentage of positive cells per 500 tumor cells was calculated. Importantly, all $\mathrm{ER}^{+}$and $\mathrm{PgR}^{+}$cases showed staining in at least $1 \%$ of the DCIS and/or invasive tumor cell nuclei, whereas all ER-negative and PgR-negative cases showed complete absence of tumor cell staining (but with staining of normal breast epithelial cell nuclei) [14].

Tumor cells were considered positive for HER2 protein overexpression when more than $10 \%$ of the cells showed strong membrane staining (equivalent to a score of $3+$ in the DakoCytomation HercepTest). HER2 2+ result was only positive if confirmed by chromogene in situ hybridization for gene amplification. All immunostains were initially reviewed and scored by a single pathologist. Hormone receptors were then reviewed and accepted as negative if $100 \%$ of cells lacked nuclear immunostaining for hormone receptors.

According to immunohistochemical features, tumors (both DCIS and invasive cancers) were divided into the following five groups: Luminal $\mathrm{A}^{(} \mathrm{ER}^{+}$and/or PgR ${ }^{+}$, HER2-negative, Ki-67 < =14\%), Luminal B1 (ER ${ }^{+}$and/or PgR ${ }^{+}$, HER2-negative, Ki-67 > 14\%), Luminal B2 (ER ${ }^{+}$and/or PgR ${ }^{+}$, HER2-positive, any Ki-67), HER2 (ER ${ }^{-}$, PgR $^{-}$, HER2-positive), and triple-negative (ER ${ }^{-}, \mathrm{PgR}^{-}, \mathrm{HER} 2$-negative) [15].

\section{Statistical analysis}

Collected data were organized in $2 \times 2$ tables and differences from expected frequencies were checked by $x^{2}$ tests.

The relative rate of tissue invasion was calculated from a simple contingency table of DCIS and IDC data according to tumor types. The probability of tumor progression (p) at the time of diagnosis for each tumor type was calculated using the following equation:

$$
p=\frac{B C}{D C I S+B C}
$$

where $B C$ stands for the number of all invasive $B C$ s for that tumor type, while DCIS is the reported number of DCIS lesions of that type. 
These results were used to calculate the number of progression $t_{1 / 2}$ intervals spent prior the time of diagnosis using the following equation:

$$
t_{1 / 2}=\frac{\log (1-p)}{\log (1 / 2)}
$$

where $p$ is the calculated probability of progression for that tumor type.

This interval is defined as a time required for $50 \%$ of DCIS lesions to become invasive. It was then converted into the relative rate $\left(v_{r e l}\right)$ using the following equation:

$$
v_{\text {rel }}=\frac{\text { tumor_type_t } t_{1 / 2}}{\text { average } t_{1 / 2}}
$$

where tumor_type_t $t_{1 / 2}$ is the number of elapsed $t_{1 / 2}$ for a certain tumor type and average $t_{1 / 2}$ is the number of elapsed intervals for all included breast tumors.

The model predictions from the ref. 1 were recalculated for the modeled population with only $5 \%$ of DCIS at the time of diagnosis. This recalculation with a similar share of DCIS tumors allowed comparison between the model results and here presented data of our patients.

\section{Results}

Table 1 shows distributions of our patients regarding breast tumor type, ER \& PgR expression, HER2 overexpression and age (younger than 55, or older than 54). Since the estrogen-dependent PgR expression occurs only in cells with functional ERs, the $\mathrm{ER}^{+} \mathrm{PgR}^{-}$tumors are considered expressing "dysfunctional" ERs.

Several comparisons were made and they can be summarized in the following statements:

- Dysfunctional ER ${ }^{+} \operatorname{PgR}^{-}$phenotype was more common in Luminal B2 (38 out of 210 cases) in comparison to the pooled Luminal A\&B1 (only 66 out of 743 cases), suggesting that this combination was more prevalent than expected in our patients $(\mathrm{p}=0.0002)$.

- If Luminal A was compared with B1, high Ki-67 values in B1 are also more often combined with the $E R^{+} \operatorname{PgR}^{-}$phenotype (40 out of 346 vs. 26 out of 397 cases, $\mathrm{p}=0.0167$ ). Thus, tumors with either HER2 overexpression, or with increased Ki-67 values seemed prone to develop the dysfunctional $\mathrm{ER}^{+} \mathrm{PgR}^{-}$phenotype.

- Age distributions were similar in the pooled Luminal A\&B1 as in B2 ( $p=0.1260)$ suggesting that age and hormone exposure did not matter much in the tumor type differentiation between these two types.

- If Luminal B2 tumors are divided according to Ki-67 value and steroid receptor phenotypes, no important differences were observed ( $\mathrm{p}=0.5489$ ), suggesting that distribution of steroid phenotypes and Ki-67 values remain unaltered in tumors with HER2 overexpression.

- On the other hand, patients' age was not important for distribution of steroid receptor phenotypes only in Luminal A patients $(\mathrm{p}=0.3789)$. In Luminal B1 patients 34 out of $40 \mathrm{ER}^{+} \operatorname{PgR}{ }^{-}$tumors were detected in patients older than 54 years. Very similar distribution was observed in Luminal B2 patients with 34 out of 38 found in patients older than 54 years. A possible conclusion is that the $\mathrm{ER}^{+} \mathrm{PgR}^{-}$phenotype is more common in tumors with high Ki-67 values or with HER2 overexpression, particularly in older patients. 
Table 1 Distributions of patients regarding breast tumor type, ER and PgR expression, HER2 overexpression and age (younger than 55 , or older than 54)

\begin{tabular}{|c|c|c|c|c|c|c|c|}
\hline & $\begin{array}{c}\text { Luminal A } \\
\text { and B1 }\end{array}$ & Luminal B2 & Total & Age & $\begin{array}{c}\text { Luminal A } \\
\text { and B1 }\end{array}$ & $\begin{array}{c}\text { Luminal } \\
\text { B2 }\end{array}$ & Total \\
\hline \multicolumn{8}{|c|}{ Distribution of breast cancer patients with positive receptors according to HER2 and age } \\
\hline $\mathrm{ER}^{+} \mathrm{PgR} \mathrm{R}^{+}$ & 666 & 172 & 838 & $<55$ & 218 & 69 & 287 \\
\hline$E R^{+} P g R^{-}$ & 66 & 38 & 104 & $>54$ & 525 & 141 & 666 \\
\hline $\mathrm{ER}^{-} \mathrm{PgR}^{+}$ & 11 & 0 & 11 & Total & 743 & 210 & 953 \\
\hline Total & 743 & 210 & 953 & & & & \\
\hline$x^{2}(p)$ & \multicolumn{3}{|c|}{$13.70(0.0002)$} & $X^{2}(p)$ & \multicolumn{2}{|c|}{$2.34(0.1260)$} & \\
\hline
\end{tabular}

Distribution of ductal breast cancer patients according to their steroid receptor phenotype and Ki-67 value

\begin{tabular}{|c|c|c|c|c|c|c|c|}
\hline $\begin{array}{c}\mathrm{ER}^{+} \text {tumors } \\
\text { without HER2 }\end{array}$ & $\begin{array}{c}\text { Luminal A } \\
(\text { Ki-67 <=14\%) }\end{array}$ & $\begin{array}{l}\text { Luminal B1 } \\
\text { (Ki-67> }>14 \%)\end{array}$ & Total & Luminal B2 & $\mathrm{Ki}-67<=14 \%$ & Ki-67> $14 \%$ & Total \\
\hline $\mathrm{ER}^{+} \mathrm{PgR}^{+}$ & 365 & 301 & 666 & $\mathrm{ER}^{+} \mathrm{PgR}^{+}$ & 49 & 123 & 172 \\
\hline $\mathrm{ER}^{+} \mathrm{PgR}^{-}$ & 26 & 40 & 66 & $E R^{+} P g R^{-}$ & 9 & 29 & 38 \\
\hline$E R^{-} \mathrm{PgR}^{+}$ & 6 & 5 & 11 & $E R^{-} P g R^{+}$ & 0 & 0 & 0 \\
\hline Total & 397 & 346 & 743 & Total & 58 & 152 & 10 \\
\hline$X^{2}(p)$ & & $.73(0.0167)$ & & $X^{2}(p)$ & 0.3 & $5(0.5489)$ & \\
\hline
\end{tabular}

Distribution of ductal breast cancer patients according to their age and other features

\begin{tabular}{|c|c|c|c|c|c|c|c|}
\hline $\begin{array}{l}\text { Age of Luminal } \\
\text { A patients }\end{array}$ & $\mathrm{ER}^{+} \mathrm{PgR}^{+}$ & $\mathrm{ER}^{+} \mathrm{PgR}^{-}$ & $\mathrm{ER}^{-} \mathrm{PgR}^{+}$ & $\begin{array}{l}\text { Age of HER2 } \\
\text { patients }\end{array}$ & $\mathrm{Ki}-67<=14 \%$ & Ki-67> $14 \%$ & Total \\
\hline$<55$ & 99 & 5 & 4 & $<55$ & 3 & 38 & 41 \\
\hline$>54$ & 266 & 21 & 2 & $>54$ & 16 & 78 & 94 \\
\hline Total & 365 & 26 & 6 & Total & 19 & 116 & 135 \\
\hline$X^{2}(p)$ & \multicolumn{2}{|c|}{$0.77(0.3789)$} & & $X^{2}(p)$ & \multicolumn{2}{|c|}{$2.22(0.1360)$} & \\
\hline $\begin{array}{l}\text { Age of Luminal } \\
\text { B1 patients }\end{array}$ & $\mathrm{ER}^{+} \mathrm{PgR}^{+}$ & $E R^{+} P_{g} R^{-}$ & $E R^{-} \mathrm{PgR}^{+}$ & $\begin{array}{l}\text { Age of triple- } \\
\text { negative patients }\end{array}$ & Ki-67 < $=14 \%$ & $\mathrm{Ki}-67>14 \%$ & Total \\
\hline$<55$ & 103 & 6 & 1 & $<55$ & 7 & 68 & 75 \\
\hline$>54$ & 198 & 34 & 4 & $>54$ & 14 & 71 & 5 \\
\hline Total & 301 & 40 & 5 & Total & 21 & 139 & 160 \\
\hline$X^{2}(p)$ & \multicolumn{2}{|c|}{$6.00(0.0143)$} & & $x^{2}(p)$ & \multicolumn{2}{|c|}{$1.78(0.1822)$} & \\
\hline $\begin{array}{l}\text { Age of Luminal } \\
\text { B2 patients }\end{array}$ & $\mathrm{ER}^{+} \mathrm{PgR}^{+}$ & $\mathrm{ER}^{+} \mathrm{PgR}^{-}$ & $E R^{-} P_{g R}^{+}$ & $\begin{array}{l}\text { Age of } \\
\text { patients }\end{array}$ & $\begin{array}{c}\text { triple- } \\
\text { negative }\end{array}$ & HER2 & Total \\
\hline$<55$ & 65 & 4 & 0 & $<55$ & 75 & 41 & 116 \\
\hline$>54$ & 107 & 34 & 0 & $>54$ & 85 & 94 & 179 \\
\hline Total & 172 & 38 & 0 & Total & 160 & 135 & 295 \\
\hline$X^{2}(p)$ & \multicolumn{2}{|c|}{$10.49(0.0012)$} & & $X^{2}(p)$ & \multicolumn{2}{|c|}{$8.36(0.0038)$} & \\
\hline
\end{tabular}

The $\mathrm{ER}^{+} \mathrm{PgR}$ - phenotype was more common in Luminal B2 in comparison to the pooled Luminal A and B1, in Luminal B1. In Luminal $\mathrm{B} 1$ and in $\mathrm{B} 2 \mathrm{ER}^{+} \mathrm{PgR}$ - tumors were more common in patients older than 54 . HER2-overexpressed patients are often older than 54.

- It is interesting that distribution of HER2-overexpressed tumor according to Ki-67 value and patients' age did not show any difference, and the same was found for triple-negative tumors. Nevertheless, if we compare age of HER2 versus triplenegative patients, HER2 patients are obviously often older than 54 years (94 out of 135 in comparison to 85 out of 160 triple-negative cases, $\mathrm{p}=0.0038$ ). This suggests that HER2 tumors might be slower in the initial growth phase so they were more often diagnosed in older patients. 
Table 2 shows results of the model of ductal cancer progression from ref. 1, applied to patients in this study. For the comparison purpose only, data from ref. 1. were recalculated to simulate population of breast tumor patients with 5\% of DCIS at the time of diagnosis. The recalculation was evidently well matched since the number of spent $T_{1 / 2}$ of progression was very similar in presented data and in the recalculated simulated population (only above $4 t_{1 / 2}$ are spent in both data sets). Relative rates were calculated relative to the average progression rate of all tumors (the average count of spent $t_{1 / 2}$ for all $\mathrm{BC}$ patients was 4.198), making the relative rates easily comparable:

- The most rapid progression was observed for Luminal B1 cancers and then for triple-negative cancers. In ref. 1 Luminal B1 cancers were not separated from other

Table 2 Results of the ductal cancer progression model from ref. 1 , applied to here presented patients

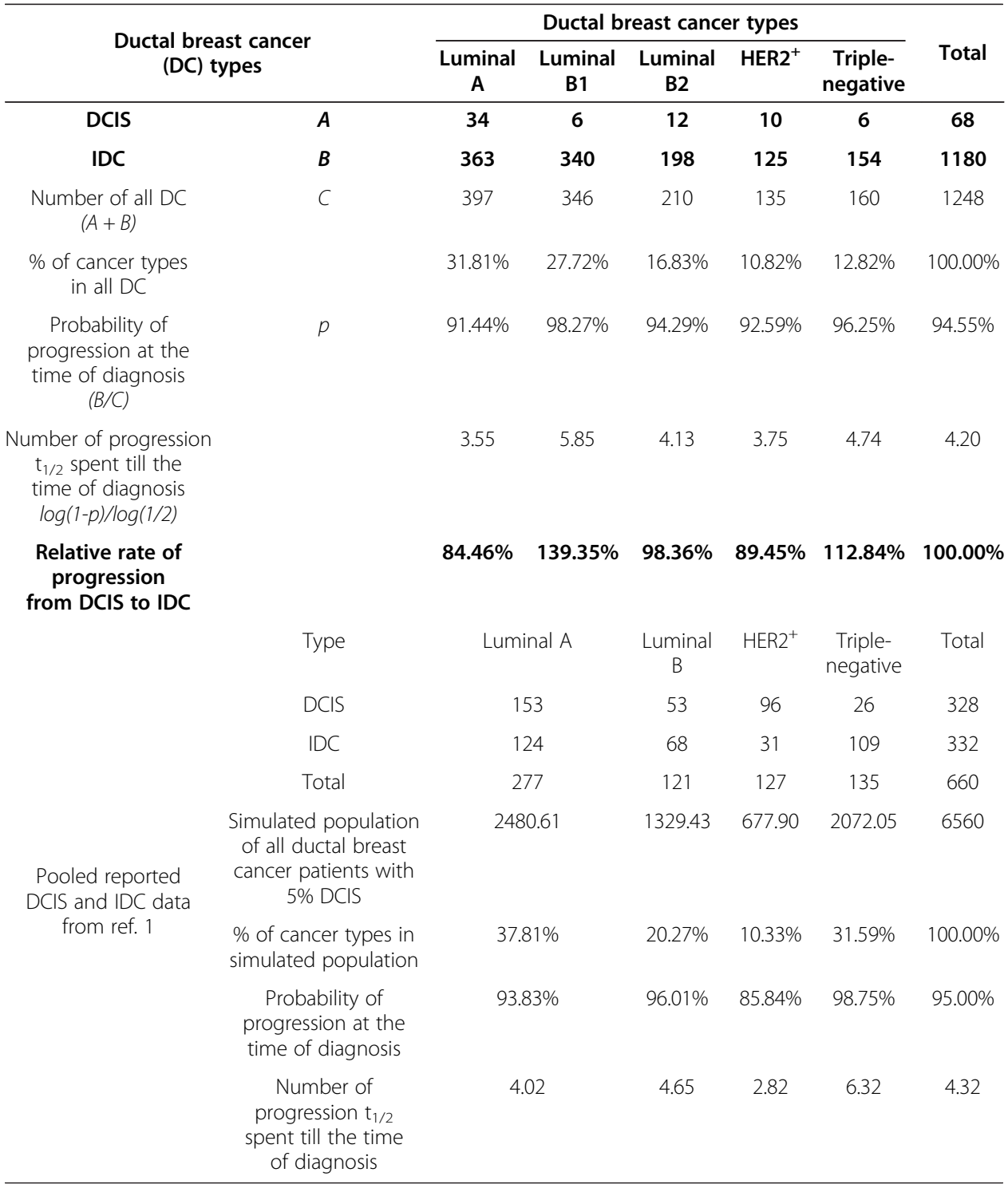

The fastest in tissue invasion were Luminal B1 cancers and then the triple-negative cancers. Based on relative rates of tissue invasion it seems that criteria for Luminal B1 have really identified the most aggressive breast cancers. 
Luminal A cancers, thus making triple-negative cancers the fastest in the relative tissue progression rate.

As Luminal B1 cancers differ from Luminal A cancers only in Ki-67 values, the same threshold of $14 \%$ Ki-67 value was applied in Table 3 to Luminal B2, HER2overexpressed and triple-negative cancers:

- Luminal B1 phenotype exceeded the average progression rate by $39 \%$, supporting the clinical importance of this phenotype. The Ki-67 subtypes of Luminal B2 (proposed in this study), HER2-overexpressed and triple-negative cancers were not so impressive.

- Low Ki-67 decreased the rate of Luminal B2 tissue progression (27\% of Luminal B2 cancers showed $91.9 \%$ of the average progression rate).

- A rare combination of low Ki-67 in HER2-overexpressed cancers (14\% of HER2 cancers) showed very slow rate of tissue invasion (only $53.55 \%$ of the average rate).

- The triple-negative cancers progressed faster than the average rate, despite the Ki-67 value (104.63\% for low and $114.27 \%$ for high Ki-67).

Table 3 Relative tissue invasion rates according to the Ki-67 value

\begin{tabular}{|c|c|c|c|c|c|c|}
\hline Binary features & & & DCIS & IDC & Relative rate & $\begin{array}{l}\text { Rate difference } \\
\text { (positive-negative) }\end{array}$ \\
\hline \multirow[t]{3}{*}{ ER } & \multicolumn{2}{|l|}{ Negative } & 16 & 290 & 1.0142 & -0.0186 \\
\hline & \multicolumn{2}{|l|}{ Positive } & 52 & 890 & 0.9955 & \\
\hline & \multicolumn{2}{|l|}{ Total } & 68 & 1180 & 1.0000 & \\
\hline \multirow[t]{3}{*}{$\mathrm{PgR}$} & \multicolumn{2}{|l|}{ Negative } & 29 & 370 & 0.9010 & 0.1577 \\
\hline & \multicolumn{2}{|l|}{ Positive } & 39 & 810 & 1.0587 & \\
\hline & \multicolumn{2}{|l|}{ Total } & 68 & 1180 & 1.0000 & \\
\hline \multirow[t]{3}{*}{ HER2 } & \multicolumn{2}{|l|}{ Negative } & 46 & 857 & 1.0231 & -0.0772 \\
\hline & \multicolumn{2}{|l|}{ Positive } & 22 & 323 & 0.9459 & \\
\hline & \multicolumn{2}{|l|}{ Total } & 68 & 1180 & 1.0000 & \\
\hline \multirow[t]{3}{*}{ Ki-67 } & \multicolumn{2}{|l|}{$<=14 \%$} & 43 & 451 & 0.8390 & 0.3317 \\
\hline & \multicolumn{2}{|l|}{$>14$} & 25 & 729 & 1.1707 & \\
\hline & \multicolumn{2}{|l|}{ Total } & 68 & 1180 & 1.0000 & \\
\hline \multirow{9}{*}{$\begin{array}{l}\text { Ductal breast cancer types } \\
\text { including Luminal B1 and } \\
\text { proposed other Ki- } 67 \text { subtypes }\end{array}$} & \multicolumn{2}{|l|}{ Luminal A } & 34 & 363 & 0.8446 & 0.5489 \\
\hline & \multicolumn{2}{|l|}{ Luminal B1 } & 6 & 340 & 1.3936 & \\
\hline & \multirow[t]{2}{*}{ Luminal B2 } & $<=14 \%$ & 4 & 54 & 0.9190 & 0.0929 \\
\hline & & $>14 \%$ & 8 & 144 & 1.0119 & \\
\hline & \multirow[t]{2}{*}{ HER2 } & $<=14 \%$ & 4 & 15 & 0.5355 & 0.4824 \\
\hline & & $>14 \%$ & 6 & 110 & 1.0179 & \\
\hline & \multirow[t]{2}{*}{ Triple-negative } & $<=14 \%$ & 1 & 20 & 1.0463 & 0.0964 \\
\hline & & $>14 \%$ & 5 & 134 & 1.1427 & \\
\hline & \multicolumn{2}{|l|}{ Total } & 68 & 1180 & 1.0000 & \\
\hline
\end{tabular}

Because Luminal B1 cancers differ from Luminal A cancers only by Ki-67 values, the same threshold of the $14 \%$ Ki- 67 value was applied to Luminal B2, HER2-overexpressed and triple-negative cancers. Luminal B1 phenotype was $39 \%$ faster than average in progression. The rare combination of low Ki-67 in HER2-overexpressed cancers (14\% of HER2 cancers) showed very slow rate of transition to IDC (only $53.55 \%$ of the average rate). 
The rates of tissue invasion for various phenotype combinations of steroid receptor expression are shown in Table 4:

- In all three tumor types with positive steroid receptors the $\mathrm{ER}^{+} \mathrm{PgR}^{-}$phenotype showed slower tissue progression rates than the functional $\mathrm{ER}^{+} \mathrm{PgR}^{+}$phenotype (by $38 \%$ for Luminal A, 46\% for Luminal B1 and 67\% for Luminal B2 with Ki67 > 14\%), suggesting that if estrogen binding to dysfunctional ERs did not promote PgR expression, it also did not stimulate tissue invasion.

Table 5 shows comparison of calculated relative rates of tissue invasion between patients younger than 55 and older patients:

- The main difference was found in patients with triple-negative tumors whose progression rate exceeded the expected average rate in younger patients by $24 \%$, while in older patients it was only $5 \%$ above the expected value.

- In HER2-overexpressed tumors, the rate of tissue invasion among older patients was $5 \%$ bellow the expected value, but in younger patients the rate was $20 \%$ lower than the expected values.

- All other features, including two steroid receptor phenotypes $\left(E R^{+} \operatorname{PgR}^{+}\right.$and $\left.E R^{-} \mathrm{PgR}^{-}\right)$ were not found to be dependent on age.

These data suggest that tumor biology in two types of ER negative tumors (HER2overexpressed and triple-negative tumors) was altered mainly in younger patients. The

Table 4 Relative tumor invasion rates according to the expression of hormonal receptors

\begin{tabular}{|c|c|c|c|c|c|c|}
\hline \multicolumn{3}{|c|}{ Combined features } & DCIS & IDC & Relative rate & Rate difference \\
\hline \multirow{5}{*}{$\begin{array}{l}\text { Ductal breast cancer } \\
\text { phenotypes of steroid } \\
\text { receptor expression }\end{array}$} & \multicolumn{2}{|c|}{$\mathrm{ER}^{+} \mathrm{PgR}^{+}$} & 39 & 799 & 1.0542 & -0.3396 \\
\hline & \multicolumn{2}{|c|}{$\mathrm{ER}^{+} \mathrm{PgR}^{-}$} & 13 & 91 & 0.7146 & \\
\hline & \multicolumn{2}{|c|}{$E R^{-} \mathrm{PgR}^{+}$} & 0 & 11 & $\mathrm{n} / \mathrm{a}$ & \\
\hline & \multicolumn{2}{|c|}{$E R^{-} P g R^{-}$} & 16 & 279 & 1.0016 & \\
\hline & \multicolumn{2}{|c|}{ Total } & 68 & 1180 & 1.0000 & \\
\hline \multirow{4}{*}{$\begin{array}{l}\text { Luminal A cancers: steroid } \\
\text { receptor phenotype }\end{array}$} & \multicolumn{2}{|c|}{$\mathrm{ER}^{+} \mathrm{PgR} \mathrm{R}^{+}$} & 28 & 337 & 0.8824 & -0.3785 \\
\hline & \multicolumn{2}{|c|}{$E R^{+} P g R^{-}$} & 6 & 20 & 0.5039 & \\
\hline & \multicolumn{2}{|c|}{$\mathrm{ER}^{-} \mathrm{PgR}^{+}$} & 0 & 6 & $\mathrm{n} / \mathrm{a}$ & \\
\hline & \multicolumn{2}{|c|}{ Total } & 34 & 363 & 0.8446 & \\
\hline \multirow{4}{*}{$\begin{array}{l}\text { Luminal B1 cancers: steroid } \\
\text { receptor phenotype }\end{array}$} & \multicolumn{2}{|c|}{$\mathrm{ER}^{+} \mathrm{PgR}^{+}$} & 4 & 297 & 1.4849 & -0.4554 \\
\hline & \multicolumn{2}{|c|}{$\mathrm{ER}^{+} \mathrm{Pg} \mathrm{R}^{-}$} & 2 & 38 & 1.0295 & \\
\hline & \multicolumn{2}{|c|}{$E R^{-} P g R^{+}$} & 0 & 5 & $\mathrm{n} / \mathrm{a}$ & \\
\hline & \multicolumn{2}{|c|}{ Total } & 6 & 340 & 1.3934 & \\
\hline \multirow{5}{*}{$\begin{array}{l}\text { Luminal B2 cancers: steroid } \\
\text { receptor phenotype }\end{array}$} & \multirow[t]{2}{*}{$<=14 \%$} & $\mathrm{ER}^{+} \mathrm{PgR}^{+}$ & 4 & 45 & 0.8606 & $\mathrm{n} / \mathrm{a}$ \\
\hline & & $\mathrm{ER}^{+} \mathrm{PgR}^{-}$ & 0 & 9 & $\mathrm{n} / \mathrm{a}$ & \\
\hline & \multirow[t]{2}{*}{$>14 \%$} & $\mathrm{ER}^{+} \mathrm{PgR}^{+}$ & 3 & 120 & 1.2756 & -0.6718 \\
\hline & & $\mathrm{ER}^{+} \mathrm{PgR}^{-}$ & 5 & 24 & 0.6038 & \\
\hline & \multicolumn{2}{|c|}{ Total } & 12 & 198 & 0.9832 & \\
\hline
\end{tabular}

In all three tumor types with positive steroid receptors the $\mathrm{ER}^{+} \mathrm{PgR}$ - phenotype showed slower transition rates to the IDC phase than the functional $\mathrm{ER}^{+} \mathrm{PgR}^{+}$phenotype ( $38 \%$ for Luminal A, $46 \%$ for Luminal B1 and $67 \%$ for Luminal B2 with Ki67 > 14\%). 
Table 5 Comparison of calculated relative rates of tissue invasion between patients younger than 55 vs. older patients

\begin{tabular}{|c|c|c|c|c|c|c|c|}
\hline \multirow[t]{2}{*}{ Features } & \multicolumn{3}{|c|}{ Age $<55$ years } & \multicolumn{3}{|c|}{ Age $>54$ years } & \multirow{2}{*}{$\begin{array}{l}\text { Rate difference } \\
\text { (older-younger }\end{array}$} \\
\hline & $\overline{\mathrm{DCIS}}$ & IDC & $\overline{\text { Relative rate }}$ & $\overline{\mathrm{DCIS}}$ & IDC & $\overline{\text { Relative rate }}$ & \\
\hline Luminal A & 8 & 100 & 0.8944 & 26 & 263 & 0.8277 & -0.0667 \\
\hline Luminal B1 & 2 & 108 & 1.3772 & 4 & 232 & 1.4013 & 0.0241 \\
\hline Luminal B2 & 4 & 65 & 0.9787 & 8 & 133 & 0.9861 & 0.0074 \\
\hline HER2 & 4 & 37 & 0.7998 & 6 & 88 & 0.9456 & 0.1458 \\
\hline Triple-negative & 2 & 73 & 1.2456 & 4 & 81 & 1.0504 & -0.1952 \\
\hline Total & 18 & 275 & 0.9588 & 44 & 565 & 0.903 & -0.0558 \\
\hline $\mathrm{ER}^{+} \mathrm{PgR} \mathrm{R}^{+}$ & 14 & 253 & 1.0151 & 25 & 546 & 1.0752 & 0.0601 \\
\hline $\mathrm{ER}^{+} \mathrm{PgR}^{-}$ & 0 & 15 & $\mathrm{n} / \mathrm{a}$ & 13 & 76 & 0.6611 & $\mathrm{n} / \mathrm{a}$ \\
\hline $\mathrm{ER}^{-} \mathrm{PgR}^{-}$ & 6 & 110 & 1.0198 & 10 & 169 & 0.9914 & -0.0284 \\
\hline Total & 20 & 378 & 1.0298 & 48 & 791 & 0.9832 & -0.0466 \\
\hline
\end{tabular}

The main difference was found in patients with triple-negative tumors that were in younger patients $24 \%$ faster than the expected average, while in older patients it was only $5 \%$ above the expected value. In HER2-overexpressed tumors, among older patients, the rate of tumor invasion was a just $5 \%$ bellow the expected value, but in younger patients the tissue invasion rate was $20 \%$ below the expected values. The ER ${ }^{+}$ER- phenotype was $33 \%$ slower than expected in older patients and incalculably fast in younger patients with no DCIS found among 15 younger patients.

progression of triple-negative tumors was faster and of HER2-overexpressed tumors slower in younger patients. A possible interpretation regarding HER2-overexpressed tumors is that invasion in these tumors depends on an as yet unidentified mechanism that takes more time to be acquired. In triple-negative tumors, some age dependent mechanism accelerated tissue invasion in younger patients, but it seemed absent after the menopause. Thus, it is possible that we should be looking for another humoral factor, possibly related to ovulatory cycles, although not dependent on the presence of estrogen or progesterone receptors.

\section{Discussion}

This study started from a theoretic paper [1] that addressed several questions regarding tumor invasion into the breast tissue. As shown in previous sections of this paper, assembling a regionally limited case series of breast cancer patients allowed complex questions to be addressed.

Several arguments can be drawn from the presented results. Among the pooled patients' results from ref. 1, Luminal A was found in near 38\% of patients and triplenegative tumors in almost 32\% of patients, Luminal B in 20\% and HER2-overexpressed in $10 \%$ of patients. In our study, the share of triple-negative tumors was smaller (near 13\%) while the pooled Luminal A \& B1 (analogous to Luminal A in ref. 1) were found in almost $60 \%$ of all patients. These differences possibly reflected the improved sensitivity of ER and PgR detection by modern immunohistochemical staining and thus reduced the proportion of triple-negative cancers (from predicted $32 \%$ in simulated population to only $12.82 \%$ found among the presented cases). This suggests that many tumors among the pooled data from ref. 1., had been classified by the then contemporary immunohistochemical methods as triple-negative, while similar tumors among our patients possibly often met the criteria for Luminal B1 tumors.

The dysfunctional $\mathrm{ER}^{+} \mathrm{PgR}^{-}$phenotype was more common in Luminal B2 in comparison to the pooled Luminal A\&B1 tumors, and also more frequent in Luminal B1 than 
in Luminal A, suggesting that tumors with HER2 overexpression, or with increased Ki-67 values were in our patients linked to this phenotype with dysfunctional ERs.

On the other hand, the same $\mathrm{ER}^{+} \operatorname{Pg} \mathrm{R}^{-}$phenotype among the three tumor types with positive steroid receptors showed slower tissue invasion than the $\mathrm{ER}^{+} \mathrm{PgR}^{+}$phenotype of the same tumor type (progression rate differences by 38\% for Luminal A, 46\% for Luminal B1 and 67\% for Luminal B2 with Ki67 > 14\%). If the presence of functional ERs is so important for tissue invasion in several breast tumor types, a plausible question is whether the efficacy of conventional hormonal therapy is compromised in patients with dysfunctional ERs (those patients with the $\mathrm{ER}^{+} \mathrm{PgR}^{-}$tumor phenotype).

Tumor progression from DCIS to IDC was found to exceed the average rate by $39 \%$ in Luminal B1 tumors, supporting the clinical importance of this tumor type. A rare combination of low Ki-67 in HER2 type cancers showed very slow tissue invasion (only $53.55 \%$ of the average rate). Triple-negative cancers showed tissue progression rates above the average, regradless of the Ki-67 value (104.63\% for the low and $114.27 \%$ for the high Ki-67 tumors). These findings suggest that high Ki-67 values might be used as a surrogate marker of an as yet unrecognized invasion promoting mechanisms in breast tumor types, except among the triple-negative cancers.

When considering age of patients and the relative rate of tissue invasions, breast tumors with the dysfunctional $\mathrm{ER}^{+} \mathrm{PgR}^{-}$phenotype progressed faster in younger patients and 33\% slower than expected in older patients. Triple-negative tumors in younger patients were $24 \%$ faster than the expected average, while in HER2overexpressed tumors, the rate of tumor invasion in younger patients was $20 \%$ lower than the expected value. A possible interpretation regarding HER2-overexpressed tumors is that invasion in these tumors depends on an unidentified mechanism that takes more time to be acquired. In triple-negative tumors, an age dependent premenopausal mechanism possibly accelerates tissue invasion without binding to ERs or PgRs (possibly activin/inhibin [16-18] or some other).

\section{Conclusions}

A previously developed theoretic model, from the pooled published breast cancer data [1], suggested that all breast cancer types evolve from DCIS lesions. If so, the more tissue invasive breast cancer types can be recognized by comparing breast tumor type distributions between DCIS lesions and invasive breast cancers, through calculation of the relative rate of tissue invasion.

By using the same approach on a case series from a single institution, the following complex results were obtained:

- Among our patients, the share of DCIS tumors was only 5.45\% of all breast cancer cases, probably reflecting late detection of breast tumors in our population.

- The fastest tissue invasion was observed among luminal B1 cancers, supporting the clinical importance of this phenotype and suggesting that the tissue invasion rate of Luminal B1 tumors depends on high Ki-67 value.

- The subgroup of 301 patients with the $\mathrm{ER}^{+} \mathrm{PgR}^{+}$phenotype of Luminal B1 tumors showed even a higher rate of tumor invasion. Beside that in all three tumor types with positive steroid receptors (Luminal A, B1 and B2), the dysfunctional ERs in the $\mathrm{ER}^{+} \mathrm{PgR} \mathrm{R}^{-}$phenotype showed slower rates of tissue invasion. These results suggest 
that ligand binding to functional breast tumor ERs, beside promoting the PgR expression, possibly also promotes tumor transition to the invasive phase.

- The rare combination of low Ki-67 in HER2-overexpressed cancers (14\% of HER2 cancers) showed very slow rate of tissue invasion. This suggests that the phenotype with low Ki-67 in HER2 type cancers might be recognized as a subgroup that longer remain in the DCIS phase at the time of diagnosis than any other cancer types.

The tested model was focused on the very early breast tumor growth phase that leads to tissue invasion, so these results are not necessary important for the subsequent clinical course of invasive ductal cancer. Nevertheless, an investigation into whether the here described subgroups also show differences in subsequent phases of cancer growth or in treatment responses seem warranted.

Competing interests

The authors declare that they have no competing interests.

\section{Authors' contributions}

SK participated in the design of the study and performed the statistical analysis, helped to draft the manuscript. Other two authors carried out reevaluation of histological slides and assembled the data base. All authors read and approved the final manuscript.

\section{Acknowledgment}

This work was funded through grants (219-2192382-2426 \& 219-2192382-2009) from the Croatian Ministry of Science and Education.

\section{Author details}

${ }^{1}$ Department of Physiology, Osijek Medical Faculty, Osijek, Croatia. ${ }^{2}$ Department of Pathology and Forensic Medicine, Osijek University Hospital, Osijek, Croatia.

Received: 2 January 2014 Accepted: 27 May 2014

Published: 11 June 2014

\section{References}

1. Kurbel S: In search of triple-negative DCIS: tumor-type dependent model of breast cancer progression from DCIS to the invasive cancer. Tumour Biol 2013, 34:1-7

2. Hoffman AW, Ibarra-Drendall C, Espina V, Liotta L, Seewaldt V: Ductal carcinoma in situ: challenges, opportunities, and uncharted waters. Am Soc Clin Oncol Educ Book 2012, 32:40-44. doi:10.14694/EdBook_AM.2012.32.40.

3. Dabbs DJ, Chivukula M, Carter G, Bhargava R: Basal phenotype of ductal carcinoma in situ: recognition and immunohistologic profile. Mod Pathol 2006, 19:1506-1511.

4. Meijnen P, Peterse $J L$, Antonini N, Rutgers EJ, van de Vijver MJ: Immunohistochemical categorisation of ductal carcinoma in situ of the breast. Br J Cancer 2008, 98:137-142.

5. Bryan BB, Schnitt SJ, Collins LC: Ductal carcinoma in situ with basal-like phenotype: a possible precursor to invasive basal-like breast cancer. Mod Pathol 2006, 19:617-621.

6. Clark SE, Warwick J, Carpenter R, Bowen RL, Duffy SW, Jones JL: Molecular subtyping of DCIS: heterogeneity of breast cancer reflected in pre-invasive disease. Br J Cancer 2011, 104:120-127.

7. Horwitz KB, Koseki Y, McGuire WL: Estrogen control of progesterone receptor in human breast cancer: role of estradiol and antiestrogen. Endocrinology 1978, 103:1742-1751.

8. Clark GM, Osborne CK, McGuire WL: Correlations between estrogen receptor, progesterone receptor, and patient characteristics in human breast cancer. J Clin Oncol 1984, 2:1102-1109.

9. Lundgren S, Kvinnsland S, Varhaug JE, Utaaker E: The influence of progestins on receptor levels in breast cancer metastasis. Anticancer Res 1987, 7:119-123.

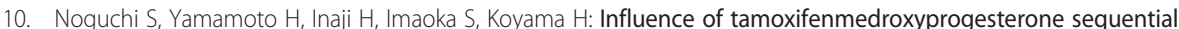
therapy on estrogen and progesterone receptor contents of breast cancer. Jpn J Cancer Res 1989, 80:244-248.

11. Classen S, Possinger K, Pelka-Fleischer R, Wilmanns W: Effect of onapristone and medroxyprogesterone acetate on the proliferation and hormone receptor concentration of human breast cancer cells. J Steroid Biochem Mol Biol 1993, 45:315-319.

12. Pujol P, Daures JP, Thezenas S, Guilleux F, Rouanet P, Grenier J: Changing estrogen and progesterone receptor patterns in breast carcinoma during the menstrual cycle and menopause. Cancer 1998, 83:698-705.

13. American Society of Clinical Oncology/College of American Pathologists: Guideline recommendations for immunohistochemical testing of estrogen and progesterone receptors in breast cancer. J Clin Oncol 2010, 28(16):2784-2795.

14. Perou CM, Sorlie T, Eisen MB, van de Rijn M, Jeffrey SS, Rees CA, Pollack JR, Ross DT, Johnsen H, Akslen LA, Fluge O, Pergamenschikov A, Williams C, Zhu SX, Lonning PE, Borresen-Dale AL, Brown PO, Botstein D: Molecular portraits of human breast tumours. Nature 2000, 406(6797):747-752. 
15. Bloom HJ, Richardson WW: Histological grading and prognosis in breast cancer; a study of 1409 cases of which 359 have been followed for 15 years. Br I Cancer 1957, 11:359-377.

16. Reis FM, Cobellis L, Tameirao LC, Anania G, Luisi S, Silva IS, Gioffre W, Di Blasio AM, Petraglia F: Serum and tissue expression of activin a in postmenopausal women with breast cancer. J Clin Endocrinol Metabol 2002, 87(5):2277-2282

17. Jeruss JS, Sturgis CD, Rademaker AW, Woodruff TK: Down-regulation of activin, activin receptors, and smads in high-grade breast cancer. Cancer Res 2003, 63:3783-3790.

18. Razanajaona D, Joguet S, Ay AS, Treilleux I, Goddard-Léon S, Bartholin L, Rimokh R: Silencing of FLRG, an antagonist of activin, inhibits human breast tumor cell growth. Cancer Res 2007, 67:7223-7229.

doi:10.1186/1742-4682-11-29

Cite this article as: Kurbel et al: A model of immunohistochemical differences between invasive breast cancers and DCIS lesions tested on a consecutive case series of 1248 patients. Theoretical Biology and Medical Modelling 2014 11:29.

\section{Submit your next manuscript to BioMed Central and take full advantage of:}

- Convenient online submission

- Thorough peer review

- No space constraints or color figure charges

- Immediate publication on acceptance

- Inclusion in PubMed, CAS, Scopus and Google Scholar

- Research which is freely available for redistribution

Submit your manuscript at www.biomedcentral.com/submit 